\title{
SOSIALISASI HAK MEWARIS ANAK ANGKAT BERDASARKAN HUKUM ISLAM DAN HUKUM ADAT UNTUK MENCAPAI KEADILAN KELUARGA
}

\author{
${ }^{1 *}$ Djanuardi, ${ }^{2}$ Hazar Kusmayanti, ${ }^{3}$ Linda Rachamainy \\ Universitas Padjadjaran \\ Email : ․ㅣanuardi@unpad.ac.id
}

Manuskrip: Okt-2020; Ditinjau: Nov -2020; Diterima: Nov-2020; Online: Jan-2021; Diterbitkan: Jan-2021

\begin{abstract}
ABSTRAK
Pengangkatan anak ini memiliki tujuan yang pada awalnya adalah untuk meneruskan keturunan ketika di dalam suatu perkawinan tidak memperoleh keturunan. Namun seiring dengan perkembangan masyarakat, tujuan pengangkatan anak ini berubah menjadi untuk kesejahteraan anak. Hal itu dapat dikatakan bahwa pengangkatan anak pada umumnya dilakukan oleh keluarga yang tidak memiliki keturunan dengan tujuan untuk mempertahankan kelangsungan ikatan perkawinan dan kebahagiaan keluarganya. Dalam pengabdian pada masyarakat ini nantinya akan memberikan penyuluhan hukum mengenai hak mewaris hak anak angkat menurut hukum Islam dan Hukum Adat oleh Tim Pengabdian Kepada Mayarakat (PPM) Fakultas Hukum Universitas Padjadjaran. Metode yang dipergunakan dalam kegiatan ini adalah diskusi terarah dengan sasaran masyarakat, diskusi ini diikuti oleh semua unsur yang berkepentingan dengan pemahaman dan untuk memahami mengenai hak mewaris hak anak angkat menurut hukum Islam dan Hukum Adat di Desa Sayang, Kecamatan Jatinangor, Sumedang dan melalui sosialisasi ini masyarakat kesadaran menjadi meningkat
\end{abstract}

\section{Kata kunci: Pengangkatan Anak, Hukum, Jatinangor}

\section{PENDAHULUAN}

Keluarga mempunyai peranan yang penting dalam kehidupan manusia sebagai makhluk sosial. Keluarga merupakan kelompok masyarakat terkecil yang terdiri dari seorang ayah, Ibu dan anak. Sebuah keluarga terbentuk dari hubungan hukum yang berupa ikatan perkawinan. Perkawinan adalah ikatan lahir bathin antara seorang pria dengan seorang wanita sebagai suami isteri dengan tujuan membentuk keluarga (rumah tangga) yang bahagia dan kekal berdasarkan Ketuhanan Yang Maha Esa. Rumusan tersebut sesuai dengan yang tercantum dalam Pasal 1 Undang-Undang No. 1 Tahun 1974 Tentang Perkawinan.

Tujuan dari suatu ikatan perkawinan adalah membentuk sebuah keluarga yang bahagia dan kekal, untuk kesejahteraan spiritual dan material. Membentuk keluarga yang bahagia erat hubungannya dengan memperoleh keturunan. Suatu keluarga baru dikatakan lengkap apabila terdiri dari seorang ayah, ibu dan anak. 
Perkawinan dapat dikatakan belum sempurna, jika pasangan suami istri belum dikaruniai anak. Oleh karena anak mempunyai kedudukan penting, maka dapat dikatakan bahwa tujuan utama dari perkawinan yang dilakukan adalah untuk memperoleh keturunan, dalam hal ini yaitu anak. Akibat dari kedudukan anak yang begitu penting, maka banyak peristiwa hukum yang dapat ditimbulkan dari ketidakhadiran anak itu dalam suatu keluarga, misalnya saja: perceraian, poligami, dan sebagainya. Jadi, seolah-olah apabila suatu perkawinan tidak memperoleh keturunan, maka tujuan perkawinan tidak tercapai. Sebaliknya, apabila di dalam suatu perkawinan telah diperoleh keturunan (anak), maka tujuan perkawinan dianggap telah tercapai.

Pengangkatan anak ini memiliki tujuan yang pada awalnya adalah untuk meneruskan keturunan ketika di dalam suatu perkawinan tidak memperoleh keturunan. Namun seiring dengan perkembangan masyarakat, tujuan pengangkatan anak ini berubah menjadi untuk kesejahteraan anak. Hal itu dapat dikatakan bahwa pengangkatan anak pada umumnya dilakukan oleh keluarga yang tidak memiliki keturunan dengan tujuan untuk mempertahankan kelangsungan ikatan perkawinan dan kebahagiaan keluarganya. Namun pengangkatan anak juga dapat dilakukan oleh keluarga yang memiliki ekonomi berkecukupan yang ingin membantu kehidupan seorang anak untuk membiayai kehidupan anak tersebut atas dasar rasa belas kasihan terhadap anak terlantar atau anak yang orang tuanya tidak mampu memeliharanya.

Undang-Undang No. 1 Tahun 1974 Tentang Perkawinan tidak mengatur dalam satu pasal pun mengenai pengangkatan anak ini. Sebelum Undang-Undang No. 1 Tahun 1974 Tentang Perkawinan ini berlaku, salah satu sistem hukum yang berpengaruh di Indonesia yaitu Hukum Barat yang dikenal dengan KUHPdt ini pun tidak mengenal tentang lembaga pengangkatan anak. Namun demikian, bagi orangorang Tionghoa yang pada umumnya tunduk pada KUHPdt dapat tunduk pada aturan Staatblad 1917 No.129, bagian II mengenai pengangkatan anak. Sehingga mengenai pengangkatan anak ini, pada awalnya hanya diatur dalam Staatblad 1917 No. 129, mengatur bahwa hanya anak laki-laki yang dapat diangkat menjadi anak angkat. Hingga akhirnya pengangkatan anak ini dapat dilakukan terhadap anak perempuan berdasarkan peraturan-peraturan yang berkembang.

Undang-Undang No. 23 Tahun 2002 Tentang Perlindungan Anak merupakan undang-undang yang mengatur salah satunya yaitu pengangkatan anak. Adapun pasal-pasal yang mengatur pengangkatan anak ini terangkum dalam Pasal 39 hingga Pasal 41 Undang-Undang No. 23 Tahun 2002 Tentang Perlindungan Anak. Adapun peraturan perundang-undangan lainnya yang mengatur mengenai pengangkatan anak ini antara lain adalah Undang-Undang No. 4 Tahun 1979 Tentang Kesejahteraan anak. Hukum Adat telah mengenal pengangkatan anak ini sejak dahulu kala, karena memang apabila suatu perkawinan tidak mendapatkan keturunan, menurut Hukum Adat dianggap bahwa keluarga itu putus keturunan. Oleh sebab itu dianjurkan bahwa anggota kerabat dapat mendesak agar suami mencari wanita lain atau mengangkat anak kemenakan dari anggota kerabat untuk menjadi penerus kehidupan keluarga bersangkutan. 
Perbedaan pengaturan dalam Hukum Adat ini disebabkan pula oleh karena adanya perbedaan sistem kekeluargaan Patrilineal, Matrilineal, dan Parental serta adanya perbedaan sistem perkawinan dan sistem pewarisan. Anak angkat menurut Hukum Adat adalah anak orang lain yang diangkat oleh orang tua angkat dengan resmi menurut hukum adat setempat, dikarenakan tujuan untuk kelangsungan keturunan dan atau pemeliharaan atas harta kekayaan rumah tangga.

Ajaran Islam mengenal adanya pengangkatan anak pada zaman Rasulullah Muhammad SAW karena Rasulullah SAW mengangkat seorang anak yang bernamaZaid bin Haristah. Pengangkatan anak dalam Islam, nasab (keturunan karena pertalian darah) tidak boleh dihilangkan. Nasab anak angkat tetap mengacu pada ayah kandungnya. Zaid tidak disebut atau dipanggil dengan Zaid bin Muhammad, melainkan Zaid bin Haristah. Jadi, anak angkat dalam Islam tetap dinisbatkan kepada ayah kandungnya. Hukum Islam mengharamkan pengangkatan anak yang bertujuan untuk mengangkat anak orang lain dengan menukar nasabnya untuk menjadi seperti anak sendiri dan dipergauli seperti anak sendiri. Adapun dasar hukumnya terdapat dalam Surat Al-Ahzab ayat (4), ayat (5), dan ayat (37). Pengangkatan anak dalam Hukum Islam memiliki makna khusus yang dapat diartikan sebagai pengangkatan anak dengan tujuan pemeliharaan, pendidikan, dan pembiayaan kehidupan anak. Ajaran Islam hanya mengenal atau hanya memperbolehkan pengangkatan anak yang memberikan status anak angkat itu sekedar mendapatkan pemeliharaan nafkah, kasih sayang, pendidikan, pelayanan kesehatan, dan hak-hak asasi sebagai anak lainnya, tanpa harus disamakan dengan status anak kandung.

Pengabdian Kepada masyarakat mengenai hak mewaris anak angkat berdasarkan hukum adat dan hukum Islam dilakukan di Desa Sayang sangat diperlukan mengingat di Desa ini masyarakat belum sepenuhnya mengerti bagaimana cara pembagian warisan menurut hukum adat dan hukum Islam. Oleh karena itu diperlukan penyuluhan hukum masyarakat untuk meningkatkan kesadaran hukum mereka akan pentingnya pengetahuan mengenai ketentuanketentuan mewaris menurut hukum adat dan hukum Islam mengingat belum ada unifikasi hukumnya di Indonesia. Hukum Waris ini sifatnya sangat sensitif karena apabila masyarakat belum paham ketentuan hukumnya maka akan berakibat sengketa.

\section{METODE PELAKSANAAN KEGIATAN}

Metode yang dipergunakan dalam kegiatan ini adalah diskusi terarah dengan masyarakat, diskusi ini diikuti oleh semua unsur yang berkepentingan dengan prosedur Bantuan hukum kepada masyarakat miskin ini diatur dalam Pasal 33 UU Nomor 16 Tahun 2011 tentang Bantuan Hukum.

Metode yang dipergunakan dalam penyuluhan hukum ini adalah diskusi terarah dengan masyarakat, diskusi ini diikuti oleh semua unsur yang berkepentingan dengan Hak Mewaris anak angkat berdasarkan bidang hukum Islam dan Hukum Adat. 
Tabel 1. Susunan Acara Pelaksanaan PKM

\begin{tabular}{|c|c|c|c|c|}
\hline \multirow{2}{*}{ No. } & \multirow{2}{*}{$\begin{array}{l}\text { Rencana } \\
\text { Kegiatan }\end{array}$} & \multicolumn{3}{|c|}{ Keterlibatan dalam kegiatan } \\
\hline & & Dosen & Mahasiswa & Masyarakat \\
\hline \multirow[t]{2}{*}{1.} & $\begin{array}{l}\text { Mengidentifikasi } \\
\text { masyarakat } \\
\text { sasaran yang } \\
\text { akan diberikan } \\
\text { penyuluhan }\end{array}$ & $\begin{array}{l}\text { Pelaksana utama } \\
\text { dalam mencari dan } \\
\text { menyiapkan data } \\
\text { masyarakat } \\
\text { sasaran untuk } \\
\text { mengikuti } \\
\text { penyuluhan } \\
\text { hukum }\end{array}$ & $\begin{array}{lr}\text { Membantu } & \text { dalam } \\
\text { mencari } & \text { dan } \\
\text { menyiapkan } & \text { data } \\
\text { masyarakat } & \\
\text { sasaran } & \text { untuk } \\
\text { mengikuti } & \\
\text { penyuluhan } & \\
\text { hukum } & \\
\end{array}$ & $\begin{array}{l}\text { Membantu dalam } \\
\text { menyediakan data } \\
\text { khususnya bagi } \\
\text { pihak yang terkait } \\
\text { mengundang } \\
\text { masyarakat sasaran } \\
\text { untuk mengikuti } \\
\text { penyuluhan hukum }\end{array}$ \\
\hline & \begin{tabular}{lr}
\multicolumn{2}{l}{ Penyuluhan } \\
hukum sesuai \\
dengan jadwal \\
yang akan \\
ditentukan \\
dengan metode \\
ceramah dan \\
tanya jawab \\
(interaktif)
\end{tabular} & $\begin{array}{l}\text { Sebagai pemateri } \\
\text { utama dalam } \\
\text { kegiatan } \\
\text { penyuluhan } \\
\text { hukum }\end{array}$ & $\begin{array}{l}\text { Membantu dalam } \\
\text { mempersiapkan } \\
\text { kegiatan } \\
\text { penyuluhan } \\
\text { hukum }\end{array}$ & $\begin{array}{l}\text { Berpartisipasi } \\
\text { dalam memberikan } \\
\text { pertanyaan hal-hal } \\
\text { yang belum } \\
\text { dimengerti } \\
\text { mengenai prosedur } \\
\text { mekanisme } \\
\text { prosedur pembagian } \\
\text { hak mewaris anak } \\
\text { angkat menurut } \\
\text { hukum adat dan } \\
\text { hukum Islam secara } \\
\text { efektif dan efisien }\end{array}$ \\
\hline 3. & $\begin{array}{l}\text { Evaluasi hasil } \\
\text { Penyuluhan } \\
\text { Hukum dengan } \\
\text { berkoordinasi } \\
\text { dengan aparat } \\
\text { pemerintah } \\
\text { setempat dan } \\
\text { lingkungan } \\
\text { sekitar } \\
\text { khususnya juga } \\
\text { para kepala } \\
\text { keluarga }\end{array}$ & $\begin{array}{l}\text { Melakukan } \\
\text { pendampingan } \\
\text { dalam proses } \\
\text { kegiatan } \\
\text { pemahaman } \\
\text { segala sesuatu } \\
\text { terkait } \\
\text { permasalahan } \\
\text { prosedur } \\
\text { pembagian hak } \\
\text { mewaris anak } \\
\text { angkat menurut } \\
\text { hukum adat dan } \\
\text { hukum Islam. }\end{array}$ & $\begin{array}{l}\text { Membantu dalam } \\
\text { melakukan } \\
\text { pendampingan } \\
\text { dalam proses } \\
\text { kegiatan } \\
\text { pemahaman } \\
\text { pembagian harta } \\
\text { warisan dan } \\
\text { permasalahannya } \\
\text { sesuai dengan } \\
\text { kapasitasnya. }\end{array}$ & $\begin{array}{l}\text { Masyarakat } \\
\text { mendapatkan } \\
\text { kepastian hukum } \\
\text { bagaimana } \\
\text { mengantisipasi } \\
\text { sebaiknya terlebih } \\
\text { dahulu terhadap } \\
\text { permasalahan hak } \\
\text { mewaris menurut } \\
\text { hukum adat dan } \\
\text { hukum islam dan } \\
\text { masyarakat dapat } \\
\text { menambah ilmu } \\
\text { sehingga juga } \\
\text { mendapat untuk } \\
\text { pemahaman } \\
\text { mengetahui } \\
\text { prosedur pembagian } \\
\text { hak mewaris anak } \\
\text { angkat menurut } \\
\text { hukum adat dan } \\
\text { hukum Islam. }\end{array}$ \\
\hline
\end{tabular}




\section{HASIL DAN PEMBAHASAN}

Pada hari Sabtu Tanggal 12 September 2020, tim PPM Riset Percepatan Lektor Kepala yang diketuai oleh Dr. H. Djanuardi. S.H., MH. melakukan penyuluhan hukum mengenai pembagian hak mewaris anak angkat menurut hukum adat dan hukum Islam.dalam rangka meningkatkan kesadaran hukum bagi masyarakat Desa Sayang Kecamatan Jatinangor. Kegiatan Penyuluhan ini diadakan di Kantor Desa Sayang Jalan Kolonel Ahmad Syam No.226, Sayang, Jatinangor, Sayang, Sumedang, Kabupaten Sumedang, Jawa Barat 45363 dengan dihadiri oleh sekitar 20 orang peserta yang terdiri dari aparatur Desa, Perwakilan pengurus Lembaga Swadaya Masyarakat, pihak kepolisian, dan anggota masyarakat. Pemaparan Penyuluhan hukum mengenai pembagian hak mewaris anak angkat menurut hukum adat dan hukum Islam, disampaikan oleh salah satu anggota tim penelitian RPLK sekaligus dosen yang pakar dalam ilmu Hukum Perkawinan dan Waris Islam yaitu Bapak Dr. H. Djanuardi, S.H.,M.H., sebagai narasumber.

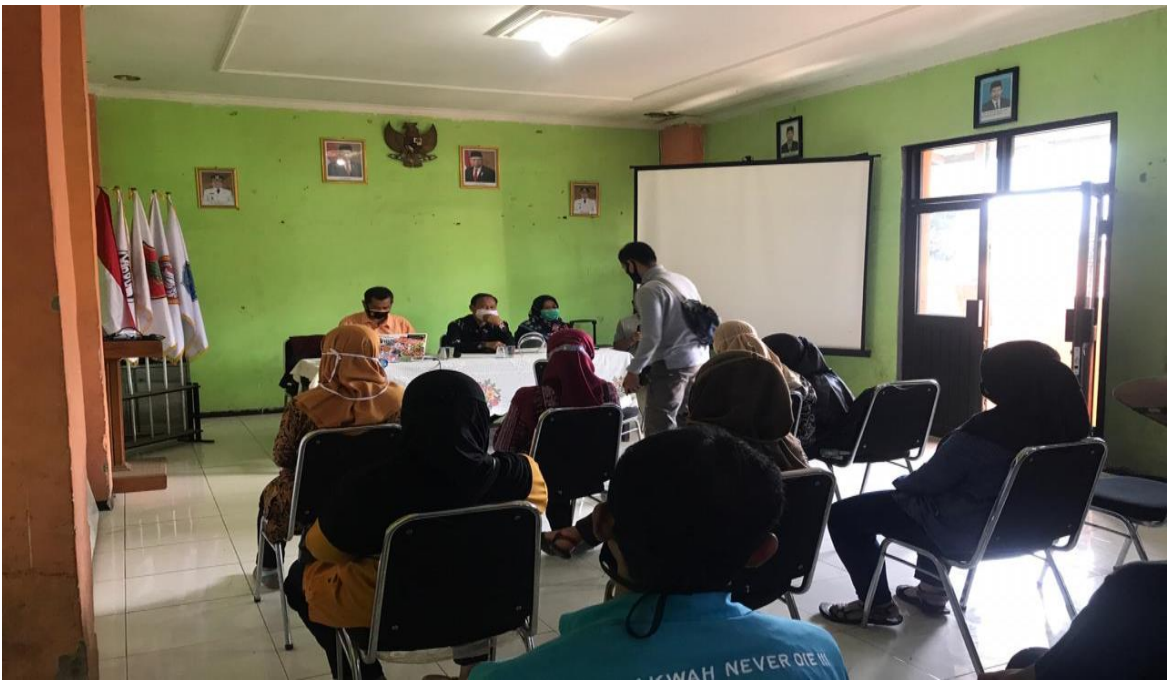

Gambar 1. Pelaksanaan PKM

Sesi Pertama adalah pemaparannya dari Dr. Dr. H. Djanuardi, S.H.,M.H menjelaskan hal-hal terkait teori-teori dan hasil dari kajian dari materi/ bahan hukum tentang pembagian warisan anak angkat berdasarkan waris adat Jawa barat dan hukum Islam.

Hukum Adat memiliki keanekaragaman sehingga pembagian ahli waris pun tergantung pada sistem kekeluargaan yang berlaku. Sistem kekeluargaan tersebut diantaranya yaitu Patrilineal, Matrilineal, dan Parental. Ahli waris dari sistem kekeluargaan Patrilineal yaitu hanya anak laki-laki, apabila salah satu meninggal dengan tidak meninggalkan anak laki-laki, maka bagian warisan itu jatuh pada kakek (ayah dari yang meninggal), dan apabila kakek tidak ada maka yang mewaris adalah saudara laki-laki yang meninggal. Sistem kekeluargaan Matrilineal, yang menjadi ahli waris adalah semua anak dari ibu, dan jika yang meninggal adalah suami, maka yang berhak mewaris ialah saudara isteri beserta anak-anak mereka. Sedangkan dalam sistem kekeluargaan Parental, yang menjadi ahli waris adalah 
semua anak-anak dari pewaris dengan pembagian sama rata. Berkaitan dengan anak angkat, Hukum Adat pun mengaturnya beraneka ragam. Ada yang setelah pengangkatan anak, anak angkat masih tetap mengakui hubungan dengan orang tua kandung, dan ada juga yang setelah pengangkatan anak hubungan antara anak angkat dan orang tua kandung menjadi terputus. Oleh sebab itu dalam Hukum Adat, anak angkat ada yang memberikan kedudukan sama dengan anak kandung, adapula yang memberikan kedudukan bukan sebagai anak kandung, dalam hal tersebut kembali lagi kepada sistem kekeluargaan adat yang dianut.

Hukum Islam mengatur adanya 3 (tiga) faktor yang menyebabkan seseorang saling mewarisi yaitu: Pertama, karena hubungan darah dekat (nasab) misalnya saja antara anak terhadap orang tua (ayah dan ibu), terhadap cucu, kakek, saudarasaudara dan sebagainya, yang mana antara mereka itu mempunyai hubungan darah dekat sebagai keturunan. Kedua, karena hubungan perkawinan misalnya antara suami isteri, yang mana keduanya tidak ada hubungan darah dekat namun karena suatu perkawinan sehingga mereka dapat saling mewarisi selama masih ada ikatan perkawinan. Ketiga, karena Wala' (perjanjian pertolongan), sesuai dalam Al-Quran Surat IV ayat 33 yang artinya sebagai berikut:

"Dan (jika ada) orang-orang yang kamu telah bersumpah setia dengan mereka dan berilah kepada mereka bagiannya, sesungguhnya Allah menyaksikan segala sesuatu."

Kedudukan anak angkat terhadap harta warisan peninggalan orang tua angkatnya berdasarkan Hukum Islam dapat dilihat dalam Surat Al-Ahzab ayat 4 dan 5 menyebutkan sebagai berikut:

"Allah tidak menjadikan anak angkatmu, jadi anak kandung bagimu. Panggillah anak angkat itu dengan nama yang disertai dengan nama ayahnya."

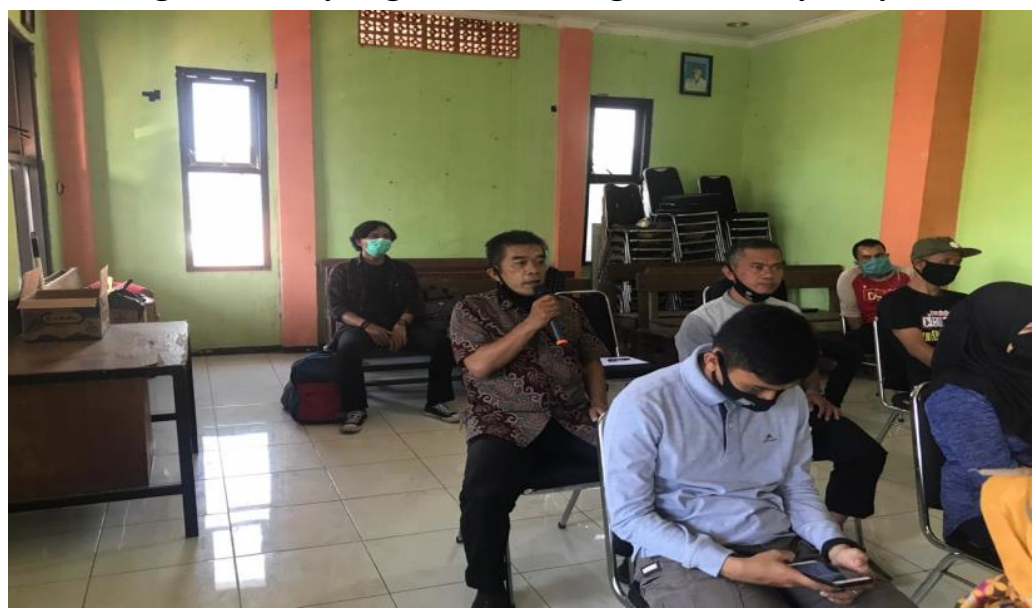

Gambar 2. Pertanyaan oleh Peserta PKM

Pada pokoknya bahwa anak angkat tidak diakui untuk dijadikan sebagai dasar dan sebab mewaris, karena prinsipnya dalam kewarisan Islam adalah hubungan darah (nasab).ukum Islam pun mengenal adanya suatu pemberian hibah ataupun wasiat. Hibah berarti pemberian sebagian harta peninggalan yang pemberiannya dilaksanakan pada semasa hidup penghibah. Pemberian hibah ini 
tidak terbatas berapa besarnya. Sedangkan wasiat merupakan pemberian sebagian harta peninggalan yang dibuat dalam suatu surat wasiat dan baru diberitahukan atau berlaku setelah pewasiat meninggal dunia. Pemberian wasiat ini besarnya pun tidak melebihi sepertiga jumlah harta peninggalan. Adapun yang dikenal dengan sebutan wasiat wajibah dalam Hukum Islam, yang merupakan suatu wasiat diperuntukkan kepada para ahli waris atau kerabat yang tidak memperoleh bagian harta warisan dari pewaris, karena adanya suatu halangan syara'. Keberadaan wasiat wajibah ini menunjukkan adanya suatu kewajiban untuk mengeluarkan sebagian harta peninggalan sebagai wasiat yang tidak lagi disandarkan kepada ada atau tidak adanya pewaris meninggalkan wasiat. Sehingga meskipun pewaris tidak berwasiat semasa hidupnya secara otomatis telah dianggap berwasiat.

Sesi Kedua adalah Diskusi dilakukan setelah pemaparan penyuluhan dilakukan, antusias dari warga pun sangat terlihat dari beberapa pertanyaan, yaitu sebagai berikut

1. Bapak Nuryaman (perwakilan dari tokoh masyarakat) : Bagaimana sebenarnya prosedur pengangkatan anak secara hukum Islam!

2. Bapak Lilik (perwakilan dari Wiraswasta) Bagaimana Penentuan waris bagi anak angkat, apabila menggunakan lembaga adat, maka akan bergantung kepada Hukum Adat yang berlaku

3. Bapak Agus (Guru sekaligus perwakilan dari Lembaga Pemberdayaan Masyarakat) Apa yang dimaksud wasiat wajibah

Sesi ketiga adalah Pembahasan pertanyaan :

1. Pengangkatan anak menurut Hukum Adat di Indonesia terdapat keanekaragaman antara daerah yang satu dengan lainnya, sesuai dengan perbedaan lingkaran Hukum Adat, seperti yang dikemukakan oleh Van Vollenhoven, bahwa di Indonesia terdapat 19 lingkaran Hukum Adat (Rechtskring), sedangkan tiap rechtskring pun terdiri dari beberapa kukuban hukum (Rechsgouw). Kalau Hukum Islam mengatur pengangkatan anak hanya dapat dibenarkan apabila memenuhi ketentuan-ketentuan sebagai berikut:

a. Tidak memutuskan hubungan darah antara anak yang diangkat dengan orang tua biologis dan keluarga.

b. Anak angkat tidak berkedudukan sebagai pewaris dari orang tua angkat, melainkan tetap sebagai pewaris dari orang tua kandungnya, demikian juga orang tua angkat tidak berkedudukan sebagai pewaris dari anak angkatnya.

c. Anak angkat tidak boleh mempergunakan nama orang tua angkatnya secara langsung kecuali sekedar sebagai tanda pengenal atau alamat.

d. Orang tua angkat tidak dapat bertindak sebagai wali dalam perkawinan terhadap anak angkatnya.

2. Penentuan waris bagi anak angkat, apabila menggunakan lembaga adat, maka akan bergantung kepada Hukum Adat yang berlaku. Hukum Waris Adat yang bersifat pluralisme, pada umumnya disebabkan oleh adanya pengaruh sistem kekeluargaan atau kekerabatan yang dianut di Indonesia. Adapun susunan atau sistem kekeluargaan tersebut antara lain: 
a. Sistem Patrilineal: sistem kekeluargaan yang menarik garis keturunan pihak nenek moyang laki-laki.

b. Sistem Matrilineal: sistem kekeluargaan yang menarik garis keturunan pihak nenek moyang perempuan

c. Parental atau Bilateral: sistem yang menarik garis keturunan dari dua sisi, baik dari pihak ayah maupun dari pihak ibu.

Pengangkatan anak merupakan salah satu cara mengangkat anak orang lain dengan maksud memelihara dan memperlakukannya seperti anak kandung sendiri. Ali Afandi mengemukakan bahwa pengangkatan anak atau istilahnya adopsi (berasal dari kata adoption) merupakan suatu tindakan mengangkat anak oleh seseorang dengan maksud untuk menganggap anak itu sebagai anaknya sendiri. Tamakiran berpendapat bahwa terdapat perbedaan ahli waris dalam hukum kekeluargaan Patrilineal, Matrilineal, dan Parental yaitu:

a. Ahli waris pada masyarakat Patrilineal, yaitu: hanya anak laki-laki, apabila salah satu meninggal dengan tidak meninggalkan anak laki-laki, maka bagian warisan itu jatuh pada kakek (ayah dari yang meninggal), dan apabila kakek tidak ada maka yang mewaris adalah saudara laki-laki yang meninggal.

b. Ahli waris pada masyarakat Matrilineal, yaitu: semua anak dari ibu, dan jika yang meninggal adalah suami, maka yang berhak mewaris ialah saudara isteri beserta anak-anak mereka.

c. Ahli waris pada masyarakat Parental, yaitu: semua anak-anak dari pewaris dengan pembagian sama rata.

3. Wasiat wajibah adalah suatu wasiat yang diperuntukkan kepada para ahli waris atau kerabat yang tidak memperoleh bagian harta warisan dari orang yang wafat, karena adanya suatu halangan syara'. Kompilasi Hukum Islam di Indonesia menyebutkan istilah wasiat wajibah untuk anak angkat dalam Pasal 209 ayat (2) yang menyatakan bahwa anak angkat yang tidak menerima wasiat diberi wasiat wajibah sebanyak-banyaknya $1 / 3$ dari harta warisan orang tua angkatnya. Hal tersebut melahirkan konsep yang mana kewajiban uontuk mengeluarkan sebagian dari harta peninggalan sebagai wasiat untuk anak angkat, tidak lagi disandarkan kepada ada atau tidaknya seseorang meninggalkan wasiat pada masa hidupnya.

\section{KESIMPULAN DAN SARAN}

Melalui Pengabdian kepada masyarakat ini peningkatan pengetahuan, pemahaman serta kemampuan para masyarakat di Desa Sayang Kecamatan Jatinangor Sumedang terkait pembagian harta warisan khususnya hak mewaris anak angkat selama 1 hari ini dapat berjalan lancar. Para peserta kegiatan PKM yang hadir bersemangat dalam mengikuti jalannya sosialisasi dan penyuluhan hukum sebab tema yang disajikan sangat aktual dalam hampir keseluruhan masyarakat Desa Sayang Jatinangor masih belum mengetahui hak mewaris dan pembagian harta warisan dilakukan sosilisasi, tingkat kesadaran hukum mereka menjadi meningkat. 


\section{DAFTAR PUSTAKA}

Ali Afandi, Hukum Waris Hukum Keluarga Hukum Pembuktian, Cet. IV, Rineka Cipta, Jakarta, 2004.

Ediwarman, Outsourcing dan Perjanjian Kerja Menurut UU No.13 Tahun 2003 tentang Andi Syamsu Alam, dan M. Fauzan, Hukum Pengangkatan Anak Persfektif Islam, Kencana Prenada Media Group, Jakarta, 2008.

Hilman Hadikusuma, Hukum Perkawinan Adat, Alumni, Bandung, 1983.

M. Budiarto, Pengangkatan Anak Ditinjau Dari Segi Hukum, Akademika Pressindo, Jakarta, 1991

Mohd. Idris Ramulyo, Hukum Perkawinan Islam, Cet. II, Bumi Aksara, Jakarta, 1999.

Mudaris Zaini, Adopsi Suatu Tinjauan Dari Tiga Sistem Hukum, Sinar Grafika, Jakarta,1992.

Purwanto, A., Sunarsi, D., \& Wijoyo, H. (2020). Penerapan Perluasan Arti Perbuatan Melanggar Hukum Dalam Pelaksanaan UU 29 Tahun 2004 (Studi Kasus Putusan No. 625/PDT. G/2014/PN JKT. BRT). TIN: Terapan Informatika Nusantara, 1(2), 99-103.

Riduan Syahrani, Seluk Beluk dan Asas-Asas Hukum Perdata, Alumni, Bandung, 2006

Tamakiran, Asas-Asas Hukum Waris Menurut Tiga Sistem Hukum, Pionir Jaya, Bandung, 2000. 